\title{
The Influence of the Role of Leadership and Compensation on Employee Performance of PT Taiho Nusantara
}

\author{
Dedi Mulyadi \\ Universitas Buana Perjuangan Karawang, Indonesia \\ Email: dedi.mulyadi@ubpkarawang.ac.id
}

\begin{abstract}
This research was conducted to find out how much influence the leadership and compensation have on the performance of the employees of PT Taiho Nusantara partially and simultaneously. The method used in this research is descriptive and verification. The population is all employees of PT Tiho Nusantara by taking 105 employee samples. The data collection techniques are through interviews, questionnaires and observations, and data analysis used Path Analysis. The results showed that the correlation between variables $X_{1}$ and $X_{2}$ obtained the magnitude of the correlation coefficient between the independent variables, namely the role of leadership $\left(X_{1}\right)$ with compensation $\left(X_{2}\right)$ can be valued at 0.875 . Thus the role of leadership $\left(X_{1}\right)$ with compensation $\left(X_{2}\right)$ has a strong and two-way relationship because of its positive value. And for the influence of the leadership role variable $(\mathrm{X} 1)$ on employee performance variables $(\mathrm{Y})$ is 0.382 . This shows that the direct influence of the leadership role variable $\left(X_{1}\right)$ on employee performance variables $(Y)$ is 0.392 so that the equation $Y=0.382 X_{1}$ is obtained. And the results for the Compensation variable $\left(\mathrm{X}_{2}\right)$ against employee performance variables $(\mathrm{Y})$ are 0.587 . This shows that the direct effect of the Compensation variable $\left(X_{2}\right)$ on employee performance $(Y)$ is equal to 0.575 so that the equation $Y=0.587 X_{2}$ is obtained. Then the path of the storage role variable $(0.382)$ is lower than the compensation variable $(0.587)$, meaning that compensation $\left(\mathrm{X}_{2}\right)$ has more influence on employee performance $(\mathrm{Y})$. While the influence of leadership roles $\left(X_{1}\right)$ and compensation $\left(X_{2}\right)$ simultaneously (overall) on employee performance $(Y)$ with the result that the value of sig. $(0,000)<\alpha(0.05)$ and $t_{\text {count }}(379,050)>$ $f_{\text {table }}(3.09)$ then $H_{0}$ is rejected. Thus it can be concluded that the role of leadership and compensation simultaneously influences the performance of its employees.
\end{abstract}

Keywords: Leadership, Compensation, Employee Performance.

\section{A. INTRODUCTION}

Improving employee performance in a company is very important because it will have a positive impact on the company and are expected to be able to increase the effectiveness and efficiency of the company (McAfee \& Champagne, 1993; Kirckpatrick, 2006). One way is through the creation of a significant leadership role. According to Raharjo \& Purbudi (1997), the success and failure of a company or organization are determined by leadership, an effective form of leadership will have an impact on the progress of the company or organization in facing the challenges and changes that occur. The role of effective leadership and good leadership figures in a company is one of the keys to success that will support the performance of its employees (Rodsutti \& Swierczek, 2002). According to Mangkunegara (2001), employee performance (work performance) is the work result in quality and quantity achieved by an employee in carrying out his duties according to the responsibilities assigned to him. Company productivity will stagnate or even 
decrease if there is no good performance management (Deming, 1981; Bloom \& VanReenen, 2011). The basis for implementing performance management is the formulation of goals; there are consensus and cooperation; it is sustainable. Twoway communication and the presence of feedback (Wibowo, 2009). Leadership includes the process of influencing in determining organizational goals, motivating follower behaviour to achieve goals, controlling to improve the group and its culture. It also affects the interpretation of the events of its followers, organizing, and activities to achieve the goal of maintaining cooperative relations and group work, obtaining support, and cooperation from people outside the group or organization (Rivai \& Mulyadi, 2012; Summerfield, 2014).

Meanwhile, Handoko (2003), argues that leadership is the ability that a person has to influence people to work to achieve goals and objectives. In reality, leaders can affect morale and job satisfaction, security, quality of work-life and especially the level of achievement of an organization. Leaders also play a critical role in helping groups, organizations or communities achieve their goals (Winston \& Patterson, 2006).

The task of a leader in managing the company is the most critical and complicated, especially in managing human resources which are the main assets in company productivity (Singh, 2008; Epstein et al., 2010). In this case, it is necessary to know that good productivity requires professionalism from employees which is the duty of a leader to be able to direct, motivate and create an attitude of professionalism from the employees in the company. If a leader has the right attitude, it will have an impact on the success of a business and vice versa (Hitt \& Duane, 2002; Van Velsor et al., 2009).

Tatehito Ueda founded PT Taiho Nusantara in 1998 in Indonesia. PT Taiho Nusantara is engaged in automotive spare parts components for two-wheeled and four-wheeled vehicles. Products produced by PT Taiho Nusantara are Engine Bearings, Bushings and Thrust Washers. The attendance data of companies that experience attendance problems, as shown in table 1.

From the table of attendance data of PT Taiho Nusantara 2014, it can be explained that the low level of attendance has not reached the target optimally, where the total target attendance rate of $94 \%$ can only be achieved $92 \%$, while the actual high level of holidays is $4 \%$ so that the achievement has not reached the target. The company wants $3 \%$. Then from the total mark, the permit rate to leave the company is $2 \%$ smaller than the actual total data of $5 \%$, for other attendance data it is by the total target data and the actual total. 
Table 1 Attendance Data of PT Taiho Nusantara

\begin{tabular}{|c|c|c|c|c|c|c|c|c|}
\hline \multirow{2}{*}{ DEPARTEMENT } & \multicolumn{2}{|c|}{ Presence } & \multicolumn{2}{c|}{ Day Off } & \multicolumn{2}{c|}{$\begin{array}{c}\text { Permission To } \\
\text { Leave the firm }\end{array}$} & \multicolumn{2}{c|}{ Other } \\
\cline { 2 - 9 } & Target & Actual & Target & Actual & Target & Actual & Target & Actual \\
\hline METAL & $94 \%$ & $93 \%$ & $3 \%$ & $6 \%$ & $2 \%$ & $\mathbf{5 \%}$ & $1 \%$ & $0,60 \%$ \\
\hline BUSHING & $94 \%$ & $92 \%$ & $3 \%$ & $3 \%$ & $2 \%$ & $\mathbf{5} \%$ & $1 \%$ & $0,30 \%$ \\
\hline WASHER & $94 \%$ & $91 \%$ & $3 \%$ & $4 \%$ & $2 \%$ & $5 \%$ & $1 \%$ & $0,10 \%$ \\
\hline C/T/S & $94 \%$ & $90 \%$ & $3 \%$ & $4 \%$ & $2 \%$ & $\mathbf{6} \%$ & $1 \%$ & $0,70 \%$ \\
\hline ADM/SUPP & $94 \%$ & $94 \%$ & $3 \%$ & $3 \%$ & $2 \%$ & $3 \%$ & $1 \%$ & $0,70 \%$ \\
\hline AVERAGE & $94 \%$ & $92 \%$ & $3 \%$ & $4 \%$ & $2 \%$ & $5 \%$ & $1 \%$ & $1 \%$ \\
\hline
\end{tabular}

Source: PT Taiho Nusantara Employment Data, 2019

This phenomenon is suspected, among others, by the inability of management to anticipate changes that occur in the organization's internal and external environment. The inability of internal management to be able to anticipate these changes that will occur can be caused by the lack of information available to be used in making an appropriate decision. The management accounting system (Management Accounting System $=$ MAS) as an essential instrument that supports management must also keep up with changes (updating) so that the information presented is relevant and long-term (future) for the benefit of management.

The compensation that PT Taiho Nusantara gave to its employees was deemed unfair and not on the same level as what they were doing. One of them is by providing appropriate facilities. By the capabilities and results provided by the employee to the company, the intended facilities are the provision of salaries and incentives by their work.

And also the compensation provided by PT Taiho Nusantara to its employees sometimes experiences delays in payment so that employees are not enthusiastic in carrying out their work. The company has determined the settlement that is given on time and the amount, and the employees know that it is considered to be able to provide satisfaction at work. But if the compensation provided by the company is late or not enough, then job satisfaction will decrease, and morale will be disturbed so that the performance of the employees decline.

Compensation is an expense and expense for the company that is given to its employees. The company expects that the compensation paid to employees can be in the form of rewards for more excellent work performance to the employees. Compensation is the thing that most influences the performance of an employee to 
work actively, where the form of compensation is one of the basic needs needed by an employee as a human being to support his life needs. Compensation must be given legally and equitably to create a conducive and productive work environment for the company. If the compensation can be done correctly, it will increase job satisfaction in the form of enthusiasm, loyalty and good work morale. Compensation provided by the company itself must be on time so that it can lead to trust from employees in the company's greater bonifidity (Hasibuan, 2002).

This compensation is a result of the application of the Manpower Law Chapter I Article, point 13, namely Workers/labourers' welfare is a fulfilment of physical and spiritual needs and / needs, both inside and outside of work relations, which directly or indirectly directly can increase work productivity. (Manpower Act, 2010).

Based on the results of interviews with company HR managers, the problems they face are the level of discipline, and there are still some employees who do not complete their assigned tasks on time. Therefore, this becomes a topic worth discussing to find out how big the leadership role in the company and the compensation given to employees can improve the performance of the employees themselves. Whether the problem is related to the leadership role in PT Taiho Nusantara or not, therefore researchers are interested in researching "The Effect of Leadership and Compensation Roles on the Performance of PT Taiho Nusantara Employees".

\section{B. METHOD}

This research uses descriptive and verification research methods. According to Sugiyono (2012), descriptive study is research conducted to see the value of the independent variable, either one or more (independent) variables without making comparisons or connecting with other variables. Meanwhile, verification research, according to Sugiyono (2010), the research method used for research on specific populations or samples, and statistical data analysis with the aim of predetermined hypotheses. Employee performance as the tested variable, while verificatively testing the hypothesis with statistical calculations.

In this study, researchers used three independent variables $\left(X_{1}\right.$ and $\left.X_{2}\right)$ and one dependent variable (Y). According to Sugiyono (2012), research variables are anything in the form that is determined by the researcher to study so that information is obtained about it, then the conclusion. The variables used are $\mathrm{X} 1$ is the influence of leadership, and variable $\mathrm{X}_{2}$ is compensation, which affects variable $\mathrm{Y}$, namely the performance of employees at PT Taiho Nusantara. At the same time, the population is all employees at PT Taiho Nusantara. Sugiyono (2012), states that the community is a generalization area consisting of objects or subjects that have certain qualities and influences that are determined by the researcher to be studied and then draw conclusions. The population taken in this study is not limited to research. Still, a preliminary investigation has been carried out to estimate the number of samples by looking for the daily data source at PT Taiho Nusantara. The population in this 
study were all employees of PT Taiho Nusantara, and the technique was incidental sampling technique, namely the sampling technique based on chance. In this case, there are 105 employees. Sugiyono (2012), says the sample is part of the number owned by the population. So the sample is anyone who happens to meet the researcher can be used as a sample if it is deemed suitable as a resource. There are two types of data: a kind of internal data and two types of external data. This study also uses two sources, one primary source and one secondary source. The data teaching techniques are interviews, questionnaires and observation and data analysis using the path (Path Analysis).

\section{RESULT AND DISCUSSION}

To obtain research data to analyze the role of leadership and compensation for the performance of PT Taiho Nusantara employees, researchers have distributed 105 questionnaires to employees of PT Taiho Nusantara. Then the results after the data were processed using SPSS 16 software, namely:

\section{Relationship Between Independent Variables}

In path analysis, the relationship between the independent variables which have a meaningful relationship can be calculated the amount of direct or indirect influence. For the indirect effect, it is the product of the path coefficient and its correlation coefficient. Therefore, the respective coefficient values between the independent variables are calculated first. For more details, the relationship between the two independent variables can be explained as follows:

Table. 2 Correlations

\begin{tabular}{|ll|r|r|}
\hline & & $X_{1}$ & \multicolumn{1}{|c|}{$X_{2}$} \\
\hline$X_{1} \quad$ Pearson Correlation & 1 & $.871^{* *}$ \\
& Sig. (2-tailed) & & .000 \\
& N & 105 & 105 \\
\hline$X_{2} \quad$ Pearson Correlation & $.871^{* *}$ & 1 \\
& Sig. (2-tailed) & .000 & \\
& N & 105 & 105 \\
\hline
\end{tabular}

**. Correlation is significant at the 0.01 level (2-tailed).

2019 Questionnaire Processing Data, SPSS 23

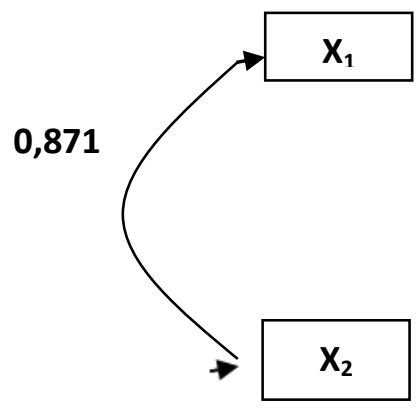

Figure 1 The relationship between the independent variables $X 1$ and $X 2$ 
From the analysis, the correlation coefficient between the independent variables, namely the role of leadership $\left(X_{1}\right)$ and compensation $\left(X_{2}\right)$, can be assessed as 0.875 . Thus the part of leadership $\left(X_{1}\right)$ with compensation $\left(X_{2}\right)$ has a strong and two-way relationship because the value is positive.

\section{Path Analysis}

Based on the results of data processing with the help of SPSS 16 software. Path coefficients were obtained for each leadership role variable $\left(X_{1}\right)$, compensation $\left(\mathrm{X}_{2}\right)$ on employee performance $(\mathrm{Y})$. The results of this analysis can be seen in the following table:

Tabel 3 Coefficients Coefficients ${ }^{a}$

\begin{tabular}{|c|c|c|c|c|c|c|}
\hline & \multirow[b]{2}{*}{ Model } & \multicolumn{2}{|c|}{ Unstandardized Coefficients } & \multirow{2}{*}{$\begin{array}{c}\begin{array}{c}\text { Standardized } \\
\text { Coefficients }\end{array} \\
\text { Beta }\end{array}$} & \multirow[b]{2}{*}{$\mathrm{t}$} & \multirow[b]{2}{*}{ Sig. } \\
\hline & & B & Std. Error & & & \\
\hline \multirow[t]{3}{*}{1} & (Constant) & 1.494 & 1.587 & & .941 & .349 \\
\hline & $X_{1}$ & .376 & .068 & .382 & 5.502 & .000 \\
\hline & $\mathrm{X}_{2}$ & .588 & .070 & .587 & 8.439 & .000 \\
\hline
\end{tabular}

a. Dependent Variable: $\mathrm{Y}$

Table 3 above shows the path coefficient value between the leadership role variables and compensation for employee performance. The path coefficient values are respectively described as follows:

a. Leadership Role variable path coefficient $\left(\mathrm{X}_{1}\right)$ on Employee Performance variable $(Y)$

Based on Table 3, the path coefficient for the leadership role variable $\left(\mathrm{X}_{1}\right)$ on the employee performance variable $(\mathrm{Y})$ is 0.382 . This shows that the direct influence of the leadership role variable $\left(\mathrm{X}_{1}\right)$ on the employee performance variable $(\mathrm{Y})$ is 0.392 so that the equation $Y=0.382 \mathrm{X}_{1}$ is obtained.

The direct effect of variable $\mathrm{X}_{1}$ on variable $\mathrm{Y}$ can be obtained in the image below:

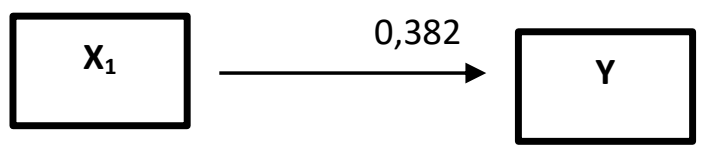

Figure 2 Partial Influence of the Role of Leadership $\left(\mathrm{X}_{1}\right)$ on Employee Performance $(\mathrm{Y})$

b. Compensation variable path coefficient $\left(\mathrm{X}_{2}\right)$ on Employee Performance $(\mathrm{Y})$

Based on Table 3, the path coefficient for the compensation variable $\left(\mathrm{X}_{2}\right)$ on the employee performance variable $(\mathrm{Y})$ is 0.587 . This shows that the direct effect of the compensation variable $\left(\mathrm{X}_{2}\right)$ on employee performance $(\mathrm{Y})$ is 0.575 so that the equation $\mathrm{Y}=0.587 \mathrm{X}_{2}$ is obtained. 
The direct effect of variable $\mathrm{X}_{2}$ on variable $\mathrm{Y}$ can be illustrated by an image, as shown below:

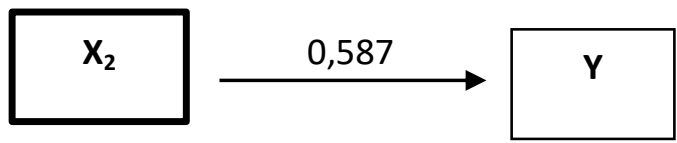

Figure 3 Partial Effect of Compensation $\left(\mathrm{X}_{2}\right)$ on Employee Performance (Y)

The partial effect of variables $X_{1}$ and $X_{2}$ on variable $Y$ can be illustrated by the picture below:

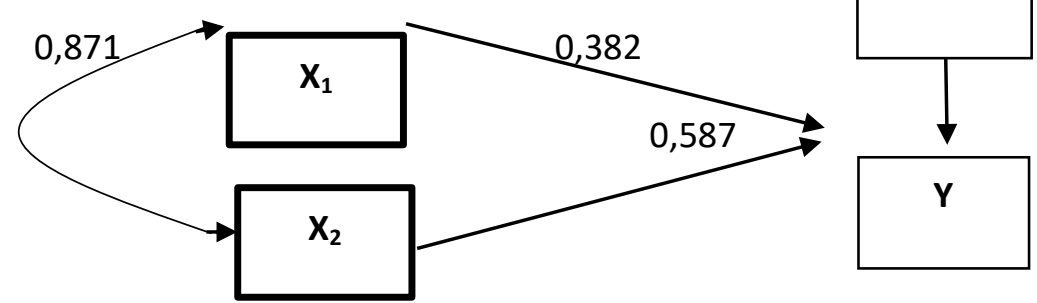

Figure 4 Direct Effect of Variables $X_{1}$ and $X_{2}$ on $Y$ (Path Analysis)

Based on Figure 4 above, it can be seen that the amount of the associative degree or the path coefficient of the storage role variable $(0.382)$ is lower than the compensation variable (0.587), meaning that compensation $\left(\mathrm{X}_{2}\right)$ has more effect on employee performance $(\mathrm{Y})$. The path equation is as follows:

$$
Y=0,382 X_{1}+0,587 X_{2}
$$

Where: $\mathrm{X}_{1}$ : Leadership Role

$\mathrm{X}_{2}$ : Compensation

Y: Employee performance

$\varepsilon$ : Another variable that is not measured but affects $Y$

c. The Influence of Variable $X$ on Variable $Y$

The direct and indirect effects simultaneously from variables $\mathrm{X}_{1}, \mathrm{X}_{2}$ on $\mathrm{Y}$ are as follows:

1) The effect of $X_{1}$ on $Y$

The influence of leadership style $\left(\mathrm{X}_{1}\right)$ on employee performance $(\mathrm{Y})$ can be seen in the following table 4.

Table 4 The Influence of the Role of Leadership ( $\left.X_{1}\right)$ on Employee Performance (Y)

\begin{tabular}{|c|l|l|r|}
\hline \multirow{2}{*}{ Variable } & \multicolumn{1}{|c|}{ Path Analysis Interpretation } & Calculation & $\begin{array}{r}\text { The amount } \\
\text { of influence }\end{array}$ \\
\hline \multirow{2}{*}{$X_{1}$} & Direct influence to Y & $0,382^{2}$ & 0,146 \\
\cline { 2 - 4 } & Indirect influence through X1 to Y & $0,382 \times 0,871 \times 0,587$ & 0,195 \\
\hline \multicolumn{2}{|c|}{ Total } & 0,341 \\
\hline
\end{tabular}

Source: Data Processing Results, 2019 
Based on Table 4, it can be seen that the influence of the leadership style variable $\left(\mathrm{X}_{1}\right)$ on employee performance $(\mathrm{Y})$ is 0.34 or $3.4 \%$.

2) Effect of $X_{2}$ on $Y$

The effect of compensation ( $\mathrm{X} 2)$ on employee performance $(\mathrm{Y})$ can be seen in the following table 5:

Table 5 Effect of compensation $\left(\mathrm{X}_{2}\right)$ on employee performance $(\mathrm{Y})$

\begin{tabular}{|c|l|r|r|}
\hline \multirow{2}{*}{ Variable } & Path Analysis Interpretation & Calculation & $\begin{array}{r}\text { The amount } \\
\text { of influence }\end{array}$ \\
\hline \multirow{2}{*}{$X_{2}$} & Direct influence on $Y$ & $0,587^{2}$ & 0,345 \\
\cline { 2 - 4 } & Indirect influence through X1 to Y & $0,382 \times 0,871 \times 0,587$ & 0,195 \\
\hline \multicolumn{2}{|c|}{ Total } & 0,540 \\
\hline
\end{tabular}

Source: Data Processing Results, 2019

Based on Table 5 above, it can be seen that the effect of the compensation variable $\left(\mathrm{X}_{2}\right)$ on the employee performance variable $(Y)$ is 0.54 or $5, \%$.

3) The effect of $X 1$ and $X_{2}$ on $Y$

The effect of the role of leadership $\left(X_{1}\right)$ and compensation $\left(X_{2}\right)$ on employee performance $(\mathrm{Y})$ can be seen in Table 6 below:

Table 6 The Influence of the Role of Leadership $\left(X_{1}\right)$ and Compensation $\left(X_{2}\right)$ on Employee Performance (Y)

\begin{tabular}{|c|c|c|c|c|c|}
\hline \multirow{2}{*}{ Variable } & \multirow{2}{*}{$\begin{array}{c}\text { Path } \\
\text { Coefficient }\end{array}$} & \multirow{2}{*}{$\begin{array}{c}\text { Direct } \\
\text { Influence }\end{array}$} & \multicolumn{2}{|c|}{$\begin{array}{c}\text { Indirect } \\
\text { Influence }\end{array}$} & \multirow{2}{*}{$\begin{array}{c}\text { Sub Total } \\
\text { Influence }\end{array}$} \\
\cline { 4 - 5 } & & $\mathbf{X}_{\mathbf{1}}$ & $\mathbf{X}_{\mathbf{2}}$ & \\
\hline $\mathrm{X} 1$ & 0,382 & 0,146 & --- & 0,195 & 0,341 \\
\hline $\mathrm{X} 2$ & 0,587 & 0,345 & 0,195 & --- & 0,54 \\
\hline \multicolumn{5}{|c|}{ Total Influence } \\
\hline
\end{tabular}

Source: Data Processing Results, 2019

Based on Table 6, it shows that the total influence of the leadership role variable $\left(\mathrm{X}_{1}\right)$ and compensation $\left(\mathrm{X}_{2}\right)$ on employee performance $(\mathrm{Y})$ is the coefficient of determination $\left(\mathrm{R}_{2}\right)$, which is 0.881 or $88.1 \%$. The other influences from outside the model amounted to $1-0.881=0.119$ or $11.9 \%$. The total effect of variables $X_{1}$ and $X_{2}$ on $\mathrm{Y}$ is stated by the coefficient of determination $\left(\mathrm{R}_{2}\right)$. The value of $\mathrm{R}_{2}$ is shown in the table below:

Tabel 7 Model Summary

\begin{tabular}{|l|r|r|r|r|}
\hline Model & \multicolumn{1}{|c|}{$\mathrm{R}$} & R Square & \multicolumn{1}{|c|}{$\begin{array}{c}\text { Adjusted R } \\
\text { Square }\end{array}$} & $\begin{array}{c}\text { Std. The error of } \\
\text { the Estimate }\end{array}$ \\
\hline 1 & $.939^{\mathrm{a}}$ & .881 & .879 & 3.71163 \\
\hline
\end{tabular}

a. Predictors: (Constant), Compensation, Role_Leadership

Based on table 7 it shows that the coefficient of determination $\left(R_{2}\right)$ is 0.881 , meaning that $88.1 \%$ of the employee performance variable $(\mathrm{Y})$ can be explained by 
the leadership role variable $\left(X_{1}\right)$ and compensation $\left(X_{2}\right)$ on employee performance (Y) of $88.1 \%$. At the same time, the remaining $11.9 \%$ is the influence of other variables not studied $(\varepsilon)$.

\section{Correlation Between the Role of Leadership (X1) and Compensation (Y)}

Hypothesis testing of the relationship between the role of leadership $\left(X_{1}\right)$ and compensation $\left(\mathrm{X}_{2}\right)$ is carried out using the $t$ statistical test, namely the following formula (Riduwan, 2012):

$$
\begin{aligned}
& \mathrm{t}=\frac{r \sqrt{n-2}}{\sqrt{1-r^{2}}} \\
& \text { Known : } \\
& \qquad \begin{aligned}
\mathrm{r} & =0.871 \\
\mathrm{n} & =105
\end{aligned}
\end{aligned}
$$

Then:

$$
\begin{aligned}
& t=\frac{0,871 \sqrt{105-2}}{\sqrt{1-0,871^{2}}} \\
& t=\frac{0,871(10,14)}{\sqrt{1-0,758}} \\
& t=8.83 / 0.87 \\
& t=10,149
\end{aligned}
$$

The value of $t_{\text {count }}$ above is then compared with $t$ table at an error rate of $5 \%$, DB $=\mathrm{n}-2=105-2=103$, then we get $\mathrm{t}$ table $=1.990$. Thus it is known that $t_{\text {count }}(10,149)>$ table $(1,990)$, it can be stated that $H_{o}$ is rejected, meaning that there is a significant relationship between the role of leadership $\left(X_{1}\right)$ and compensation $\left(X_{2}\right)$.

\section{The hypothesis of Partial Influence of Variables}

Hypothesis analysis has a partial effect between each independent variable on the dependent variable as follows:

a. The hypothesis of the Partial Influence of the Role of Leadership $\left(X_{1}\right)$ on Employee Performance (Y)

The effect of partial leadership style on employee performance can be seen through statistical testing using the following hypothesis:

$\mathrm{H}_{\mathrm{o}}$ : $\mathrm{pyx}_{1}=0$ : There is no influence on the role of leadership on employee performance

$H_{1}: \operatorname{pyx}_{1} \neq 0$ : There is an influence of the role of leadership on employee performance

Test Criteria: Reject $\mathrm{H}_{\mathrm{o}}$ if Sig. $<\alpha$ or $\mathrm{t}_{\text {count }}>\mathrm{t}_{\text {table }}$

For the partial influence of the role of leadership on employee performance with a significant level $(\alpha)=5 \%$, degree of freedom $(\mathrm{df})=(\mathrm{n}-2)=105-2=103$ obtained $\mathrm{t}$ table $=1.990$. Based on Table 8 above, it shows that $t_{\text {count }}=5.502$ and sig. 0,000. The effect of $X_{1}$ partially on $Y$ is shown in table 9 as follows: 
Table 9 Partial Influence of Leadership Style (X1) on Employee Performance (Y)

\begin{tabular}{|c|c|c|c|c|c|}
\hline Structural & Sig. & A & $\mathbf{T}_{\text {count }}$ & $\mathbf{t}_{\text {table }}$ & Conclusion \\
\hline pyx $_{1}$ & 0,000 & 0,05 & 5,502 & 1,990 & Horejected \\
\hline
\end{tabular}

Source: Data Processing Results, 2019

Table 9 shows that the sig. $(0,000)<\alpha(0.05)$ and $t_{\text {count }}(8,439)>t$ table $(1,990)$ then $H_{o}$ is rejected. Thus it can be concluded that compensation partially affects employee performance.

b. Hypothesis Partially Compensation $\left(\mathrm{X}_{2}\right)$ on Employee Performance $(\mathrm{Y})$

The effect of partial compensation on employee performance can be seen through statistical testing using the following hypothesis:

$\mathrm{H}_{\mathrm{o}}:$ pyx $_{2}=0$ : There is no effect of compensation on employee performance.

$\mathrm{H}_{1}: \operatorname{pyx}_{2} \neq 0$ : There is an effect of compensation on employee performance.

Test Criteria: Reject Ho if Sig. $<\alpha$ or $t_{\text {count }}>$ table

For the effect of partial compensation on employee performance with a significant level $(\alpha)=5 \%$, degree of freedom $(\mathrm{df})=(\mathrm{n}-2)=105-2=103$, the $t_{\text {table }}$ is 1.990. Based on Table 10, it shows that $t_{\text {count }}=8.439$ and sig. 0,000 . The partial effect of $\mathrm{X} 2$ on $\mathrm{Y}$ is shown in table as follows:

Table 10 Partial Effect of Compensation (X2) on Employee Performance (Y)

\begin{tabular}{|l|l|l|l|l|l|}
\hline Structural & Sig. & A & $\mathbf{T}_{\text {count }}$ & $\mathbf{t}_{\text {table }}$ & conclusion \\
\hline Pyx 2 & 0,000 & 0,05 & 8,439 & 1,990 & Horejected \\
\hline
\end{tabular}

Source: Data Processing Results, 2019

Table 10 shows that the sig. $(0,000)<\alpha(0.05)$ and $t_{\text {count }}(8,439)>t_{\text {table }}(1,990)$ then $H_{o}$ is rejected. Thus it can be concluded that compensation partially affects employee performance.

\section{Simultaneous Variable Influence Hypothesis}

The effect of the role of leadership $\left(X_{1}\right)$ and compensation $\left(X_{2}\right)$ simultaneously (overall) on employee performance $(\mathrm{Y})$ can be seen through statistical testing using the following hypothesis:

$H_{o}: p x_{1}=p_{1} x_{2}=0$ : There is no influence of leadership style and compensation on employee performance.

$\mathrm{H}_{1}: \operatorname{pyx}_{1} \neq \operatorname{pyx}_{2} \neq 0$ : There is an influence of leadership style and compensation on employee performance.

Test Criteria: Reject $\mathrm{H}_{\mathrm{o}}$ if Sig. $<\alpha$ or $\mathrm{t}_{\text {count }}>$ table

For the effect of the role of leadership and compensation simultaneously on employee performance with a significant level $(\alpha)=5 \%$, degree of freedom $(\mathrm{df})=(\mathrm{n}$ $2)=105-2=103$, obtained $f_{\text {table }}=3.09$. While $f_{\text {count }}$ can be seen in the table 10 below: 
Table 11 Calculation Results of the F

ANOVA

\begin{tabular}{|c|c|c|c|c|c|c|}
\hline \multicolumn{2}{|c|}{ Model } & Sum of Squares & $\mathrm{df}$ & $\begin{array}{c}\text { Mean } \\
\text { Square }\end{array}$ & $\mathrm{F}$ & Sig. \\
\hline \multirow[t]{3}{*}{1} & Regression & 10443.743 & 2 & 5221.871 & 379.050 & $.000^{\mathrm{a}}$ \\
\hline & Residual & 1405.171 & 102 & 13.776 & & \\
\hline & Total & 11848.914 & 104 & & & \\
\hline
\end{tabular}

a. Predictors: (Constant), $\mathrm{X}_{2}, \mathrm{X}_{1}$

b. Dependent Variable: $Y$

Source: Data Processing Results, 2019

Based on Table 11 above, it shows that $F_{\text {count }}=379.050$ sig. 0,000. The simultaneous effect of $\mathrm{X}_{1}$ and $\mathrm{X}_{2}$ on $\mathrm{Y}$ is shown in Table 12 below:

Table 12 The simultaneous effect of leadership style (X1) and compensation $(\mathrm{X} 2)$ on employee performance $(\mathrm{Y})$

\begin{tabular}{|c|c|c|c|c|c|}
\hline Structural & Sig. & A & F $_{\text {count }}$ & $\mathbf{f}_{\text {table }}$ & Conclusion \\
\hline${\text { Pyx } 1 \mathrm{x}_{2}}$ & 0,000 & 0,05 & 379,050 & 3,09 & Horejected \\
\hline
\end{tabular}

Source: Data Processing Results, 2019

Table 12 shows that the sig. $(0.000)<\alpha(0.05)$ and count $(379.050)>F_{\text {table }}(3.09)$ then $\mathrm{H}_{\mathrm{o}}$ is rejected. Thus it can be concluded that the role of leadership and compensation has a simultaneous effect on employee performance.

\section{CONCLUSION}

Based on the data analysis that has been stated, it can be concluded that the results of the study show that for the correlation between variables $X_{1}$ and $X_{2}$, the correlation coefficient between the independent variables, namely the role of leadership $\left(X_{1}\right)$ and compensation $\left(X_{2}\right)$, can be assessed at 0.875 . Thus the role of leadership $\left(X_{1}\right)$ with compensation $\left(X_{2}\right)$ has a strong and two-way relationship because the value is positive. And the influence of the leadership role variable $\left(X_{1}\right)$ on the employee performance variable $(\mathrm{Y})$ is 0.382 . This shows that the direct influence of the leadership role variable $\left(X_{1}\right)$ on the employee performance variable $(\mathrm{Y})$ is 0.392 so that the equation $\mathrm{Y}=0.382 \mathrm{X}_{1}$ is obtained. And the results for the variable compensation $\left(\mathrm{X}_{2}\right)$ to the employee performance variable $(\mathrm{Y})$ is 0.587 . This shows that the direct effect of the compensation variable $\left(X_{2}\right)$ on employee performance $(\mathrm{Y})$ is 0.575 so that the equation $\mathrm{Y}=0.587 \mathrm{X} 2$ is obtained. Then the path of the storage role variable $(0.382)$ is lower than the compensation variable $(0.587)$, meaning that compensation $\left(X_{2}\right)$ has more effect on employee performance $(Y)$. While the influence of the role of leadership $\left(X_{1}\right)$ and compensation $\left(X_{2}\right)$ simultaneously (overall) on employee performance $(Y)$ with the result that the value of sig. $(0.000)<\alpha(0.05)$ and $t_{\text {count }}(379.050)>f_{\text {table }}(3.09)$ then $H_{o}$ is rejected. Thus it can 
be concluded that the role of leadership and compensation has a simultaneous effect on employee performance.

\section{REFERENCES}

1. Bloom, N., \& Van Reenen, J. (2011). Human Resource Management and Productivity. In Handbook of Labor Economics, 4, 1697-1767.

2. Deming, W. E. (1981). Improvement of Quality and Productivity through Action by Management. National productivity review, 1(1), 12-22.

3. Epstein, M. J., Buhovac, A. R., \& Yuthas, K. (2010). Implementing Sustainability: The Role of Leadership and Organizational Culture. Strategic finance, 91(10), 41.

4. Handoko, H. T. 2003. Manajemen. Yogyakarta: BPFE-Yogyakarta.

5. Hasibuan, M. (2002). Manajemen Sumber Daya Manusia. Jakarta : BumiAksara

6. Hitt, M. A., \& Duane, R. (2002). The Essence of Strategic Leadership: Managing Human and Social Capital. Journal of Leadership E Organizational Studies, 9(1), 314.

7. Kirkpatrick, D. L. (2006). Improving employee performance through appraisal and coaching. Amacom Books.

8. Mangkunegara, A. A. P. (2016). Manajemen Sumber Daya Manusia Perusahaan. Badung : Remaja Rosdakarya..

9. Manpower Act 2010

10. McAfee, R. B., \& Champagne, P. J. (1993). Performance Management: A Strategy for Improving Employee Performance and Productivity. Journal of Managerial Psychology.

11. Rahardjo, M., \& Purbudi. (1997). Manajemen Sumber Daya Manusia. Yogyakarta: UPN.

12. Rivai, V., \& Mulyadi, D. (2003). Kepemimpinan dan Perilaku Organisasi. Jakarta: Raja Grafindo Persada.

13. Singh, S. K. (2008). Role of Leadership in Knowledge Management: A Study. Journal of knowledge management.

14. Sugiyono. (2012). Metode Penelitian Kuantitatif Kualitatif dan RED. Bandung : Alfabeta

15. Summerfield, M. R. (2014). Leadership: A Simple Definition. American Journal of Health-System Pharmacy, 71(3), 251-253.

16. Van Velsor, E., Hind, P., Wilson, A., \& Lenssen, G. (2009). Developing Leaders For Sustainable Business. Corporate Governance: The international journal of business in society.

17. Wibowo. (2009). Manajemen Kinerja. Jakarta: Raja Grafindo Persada

18. Winston, B. E., \& Patterson, K. (2006). An Integrative Definition of Leadership. International journal of leadership studies, 1(2), 6-66. 